Finanse, Rynki Finansowe, Ubezpieczenia nr 4/2016 (82), cz. 2

\title{
The Impact of the Global Financial Crisis on the Value Relevance of Leverage in the Polish Banking Sector
}

\author{
Piotr Bolibok*
}

\begin{abstract}
Purpose - The paper is an empirical investigation of the impact of the global financial crisis on the value relevance of leverage in the Polish banking sector.

Design/methodology/approach - The employed research methods include multiple linear regression analysis and the Chow test for a structural break in the model's parameters. The examined sample covers all domestically-based commercial banks listed on the Warsaw Stock Exchange over the period 1998-2014.

Findings - The results of the research indicate that the perception of financial leverage by equity investors in the Polish banking sector has changed significantly since the beginning of the global financial crisis. In the period preceding the crisis leverage appeared to have a positive, yet not significant, impact on banks' market value. After the crisis started, however, this impact became significantly negative which might reflect a structural change in investors' attitudes, resulting from considerably increased uncertainty and risk aversion in that period.

Originality/value - The empirical evidence on the impact of the global financial crisis on the value relevance of leverage in the banking sector in the existing literature seems to be limited to the context of the U.S. market. In particular, it appears that no prior study has investigated this problem in the specific setting of the Polish capital market. The present study attempts, therefore, to enhance the existing international and domestic literature by filling this apparent gap.
\end{abstract}

Keywords: banks; market value, leverage, financial crisis, value relevance.

\section{Introduction}

The role of banks as financial intermediaries affects numerous aspects of their business activities, in particular the specificity of their capital structure. Commercial banks typically run their operations relying mostly on debt financing resulting, above all, from deposits made by their clients. In the effect, the extent of financial leverage in the banking industry, measured in relation to total assets over total shareholder funds, is usually several times higher than that of the non-financial enterprise sector (BIS 2010, p. 75).

According to the Modigliani-Miller (1958) theorem, in a perfectly efficient capital market, in the "world" without information asymmetry, taxes, and agency or bankruptcy costs, a firm's capital structure should be value-irrelevant to equity investors. The reality,

\footnotetext{
* dr Piotr Bolibok, Katolicki Uniwersytet Lubelski Jana Pawła II, e-mail: piotr.bolibok@kul.pl.
} 
however, is quite distant from this idealistic view, as diverse market imperfections might render a company's capital structure (in particular the extent of leverage) important in making investment decisions.

Given sufficiently high operating efficiency, the use of financial leverage enables to increase the return on equity above the return on assets, which provides the owners of a company with additional benefits. The leverage, however, is a "double-edged sword", so when operating efficiency becomes too low to sustain the burden of debt service, the costs of debt begin to drag earnings down, often leading to losses and increased bankruptcy risk. Therefore, from the shareholders' perspective leverage increases the volatility of stock returns and thus the riskiness of investment (Yang, Tsatsaronis 2012, p. 49).

In the specific context of the banking industry, during the periods of favourable macroeconomic conditions higher leverage leads to greater returns on equity resulting in increasing the market value of banks' stocks. As the conditions become worse, however, higher leverage might amplify the adverse effects of potential losses, in particular those related to asset impairment, and in this way increase the risk of bankruptcy. This, in turn, might lead to fall in the market value resulting from the increased risk aversion of the equity investors. Additionally, although leverage improves the short-run efficiency of resource allocation in the banking sector, in the long-run it creates a strong systemic risk increasing the frequency and duration of financial crises (Phelan 2016).

Given the above intuition, the paper investigates the impact of financial leverage on the market value of banks in the periods preceding and succeeding the last global economic crisis in the specific context of the emerging capital market of Poland. To the author's knowledge to date this issue has not been directly examined empirically, therefore the present study attempts to contribute to the existing literature by filling this apparent gap.

The remainder of the paper is organised in three sections. The first section provides a review of international and domestic literature regarding the value relevance of bank's capital adequacy and leverage. The second section describes the methodological framework of the paper and the data selection procedures. The main findings of the study are presented and discussed in Section 3. The paper is closed with conclusions and some suggestions on the directions of any future research.

\section{Literature review}

Being a fundamental indicator of banks' financial stability and the overall riskiness of their operations, capital adequacy should be of crucial importance for investors in the banking industry. Equity capitalization might be treated as a source of market power, for banks with higher capital ratios tend to be more flexible in their operations and more capable of exploiting growth opportunities that arise on the market. Furthermore, they are less exposed to regulatory risks and costs, for instance those related to restrictions on operations imposed by regulators (e.g. prohibitions on engaging in new activities or dividend payouts) 
or preparation of recovery plans (Calomiris, Nissim 2012, p. 21). In this light, banks' capital adequacy is supposed to be positively related to their market values, while higher leverage should be priced negatively by the capital market.

Direct evidence supporting the above view is provided by Jordan et al. (2011) who examined a sample of over 750 U.S. banks and savings and loans institutions over the period 2006-2009 finding a statistically significant positive impact of the ratio of Tier 1 capital to total assets on the market-to-book ratio, after controlling for size and other bank-specific attributes. Additionally, numerous studies report a strong, positive relation between the book values of equity and banks' market values both in an international and domestic setting (see e.g. Abuzayed et al. 2009; Agostino et al. 2011; Anandarajan et al. 2011; Mehran and Thakor 2011; Bolibok 2014).

On the other hand, however, the sense of protection provided by the safety net solutions, including deposit insurance and potential government bailouts, inclines investors to purchase the shares of banks that undertake higher leverage in search of greater returns on equity (Calomiris, Nissim 2012, p. 22). In the light of agency models, debt financing might be in fact preferred by equity investors as it puts hard constraints on banks' management (see e.g. Hart, Moore 1995) while equity provides a protective cushion against erroneous business decisions. In turn, constraints resulting from regulatory capital requirements impose value-relevant costs which adversely affect banks' market values (Allen et al. 2011).

Excessive equity might also be perceived negatively by the capital market as an indicator of the relatively higher riskiness of operations or holdings of opaque assets that require a larger capital cushion (Calomiris, Wilson 2004). It can also suggest the lower ability of the management to select positive net present value investments or exploit the net benefits from leverage (Calomiris, Nissim 2012, p. 22).

Moreover, the findings of Cheng et al. (2010) suggest that institutional investors, e.g. mutual funds, might even put direct pressure on financial institutions encouraging them to undertake greater leverage in exchange for higher demand for their shares, resulting eventually in higher market values.

The above arguments suggest therefore that under certain circumstances higher leverage might be in fact rewarded by the capital market, which could result in an inverse relationship between capital adequacy and banks' market values.

Extensive international research by Kalemli-Ozcan et al. (2011), covering the sample of over 32,000 banks from 68 countries in the period 1996-2009, shows that the increase in leverage prior to the crisis was most noticeable for large banks (especially investment ones) from the developed countries. These institutions were aggressively increasing their balance sheets using debt during asset booms. In turn, smaller banks on average did not experience significant increases in leverage ratios. This pattern was most pronounced in the U.S. and to a lesser extent in Europe. Additionally, the research revealed that banks operating in the emerging markets were less aggressively increasing their leverage ratios before the crisis and were able to maintain them during it. 
Using the data covering the period 2000-2011 for the sample of U.S. banks, Calomiris and Nissim (2012) found that the impact of leverage on the market value of banks changed during the recent financial crisis. Prior to the crisis leverage increased the market-to-book ratio, but once the downturn began this relationship became reversed, as highly-leveraged banks found themselves more exposed to counterparty risk that negatively affected their operations, often forcing them to liquidate assets and struggle for strengthening their financial position. This in turn led to the negative perception of leverage by the equity investors and its adverse impact on banks' market value.

In the light of the results of previous studies leverage appears to be a value-relevant factor in the banking sector. The direction of its impact on the market value of banks remains, however, it is ambiguous. Additionally, the aforementioned findings of Calomiris and Nis$\operatorname{sim}$ (2012) regarding the U.S. market suggests that this impact may vary along the course of the business cycle. It also appears that to date no study has attempted to examine the above issues in the specific context of the Polish banking sector.

\section{Research framework}

In the light of the evidence present in the relevant literature, the impact of leverage on the market value of banks appears to be ambiguous. Undoubtedly, however, the recent global financial crisis has increased the overall risk aversion of equity investors around the world, which might result in a more negative perception of leverage also in the Polish banking sector. The above intuition led to the formulation of the following research hypothesis:

H1: The global financial crisis has resulted in a more negative perception of leverage by equity investors in the Polish banking sector.

In order to test the above hypothesis a multiple regression analysis was employed. Given the fact that earlier empirical evidence in both international and domestic settings indicates that banks' market value is strongly related to the book values of equity and net earnings these accounting items were included in the regression model as explanatory variables together with the ratio of total assets to equity used as a measure of the extent of financial leverage. The basic regression model took the following form, further referred to as Model 1:

$$
\tilde{p}_{t}=\alpha_{0}+\alpha_{1} \times B V P S_{t}+\alpha_{2} \times E P S_{t}+\alpha_{3} \times L_{t}+\varepsilon_{t},
$$

where:

$\tilde{p}_{t} \quad-$ closing price of a bank's share at the end of year $t$,

$\alpha_{0} \quad-$ intercept,

$\alpha_{1}, \alpha_{2}, \alpha_{3}-$ structural parameters,

$B V P S_{t} \quad-$ book value per share at the end of year $t$,

$E P S_{t} \quad-$ net earnings per share for the year $t$, 


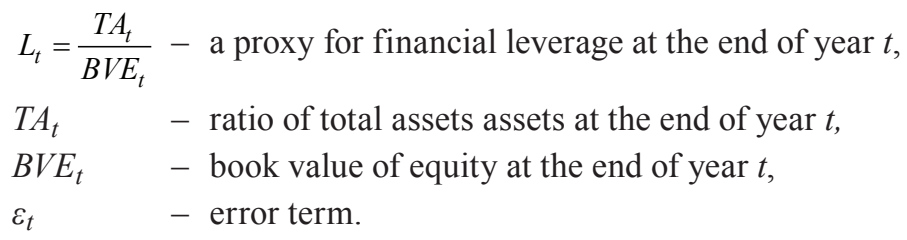

The estimates of parameters $\alpha_{1}$ and $\alpha_{2}$ are expected to be positive both before and after the beginning of the global financial crisis in 2008. In the light of the evidence in the relevant literature the sign of the coefficient $\alpha_{3}$ cannot be unambiguously predetermined; however, the estimated value of this coefficient is expected to decrease in the period succeeding the crisis due to increasing uncertainty and risk in the capital markets. The presence of an error term serves for capturing the influence of factors not included in the model.

To test the statistical significance of the differences in the regression coefficients between the examined periods the Chow test for structural change was employed. The Chow test statistic is given by the following equation (Dougherty 2001, pp. 245-246):

where:

$$
F(k, n-2 k)=\frac{\left(R S S_{P}-R S S_{A}-R S S_{B}\right) / k}{\left(R S S_{A}+R S S_{B}\right) /(n-2 k)},
$$

$R S S_{P} \quad-$ total sum of the squares of the residuals in the pooled regression,

$R S S_{A}, R S S_{B}-$ residual sums of squares for the subsample regressions $\mathrm{A}$ and $\mathrm{B}$, respectively,

$n \quad-$ number of observations in the pooled sample,

$k \quad-$ number of parameters in the regression model.

The Chow test statistic follows the $\mathrm{F}$ distribution with $(k, n-2 k)$ degrees of freedom. The null hypothesis assumes the equality of the regression coefficients in the examined subsamples. The value of the test statistic exceeding the corresponding critical value of the F distribution implies a rejection of the null hypothesis, thus indicating a structural break in the regression parameters (i.e. a statistically significant difference between the values of regression coefficients in each subsample).

To test the statistical significance of the changes in the regression coefficients after the beginning of the financial crisis Model 1 was extended to the following form (further referred to as Model 2):

$$
\begin{gathered}
\tilde{p}_{t}=\beta_{0}+\beta_{1} \times D_{t}+\beta_{2} \times B V P S_{t}+\beta_{3} \times E P S_{t}+\beta_{4} \times L_{t}+\beta_{5} \times\left(D_{t} \times B V P S_{t}\right)+ \\
+\beta_{6} \times\left(D_{t} \times E P S_{t}\right)+\beta_{7} \times\left(D_{t} \cdot L_{t}\right)+\vartheta_{t}
\end{gathered},
$$

where:

$\beta_{0} \quad-$ intercept,

$\beta_{1}, \beta_{2}, \ldots, \beta_{7}-$ structural parameters, 
$D_{t}$ - a dummy variable equal 0 for $t=1998,1999, \ldots, 2007$ and 1 for $t=2008,2009, \ldots$, 2014 ,

$\vartheta_{t}-$ error term,

the remaining symbols as in Model 1.

Estimates of the parameters $\beta_{5}, \beta_{6}$ and $\beta_{7}$ of Model 2 correspond to changes in the regression coefficients for the book value of equity, net earnings and leverage, respectively, between the periods 1998-2007 and 2008-2014.

The research covered all domestically-based commercial banks listed on the Warsaw Stock Exchange over the period 1997-2014. After taking into account the results of mergers and acquisitions within the sector over the examined time span, the final sample comprised of 18 banks. The data on annual financial statements were collected from the Notoria Serwis SA database provided by ISI Emerging Markets (http://site.securities.com... 2015). As the research aims to investigate the value relevance of leverage in the banking sector, the analyses were based on the data from the separate financial statements of banks. Historical stock prices were collected from the database of the Brokerage House of Bank Ochrony Srodowiska SA (http://bossa.pl... 2015). The combined data on stock prices and selected accounting variables yielded the final pooled sample of 234 bank-year observations ( 138 for the period 1998-2007 and 96 for the period 2008-2014).

\section{Empirical results}

The results of the estimations of Model 1 parameters for the periods preceding and succeeding the global financial crisis, as well as for the entire examined time span, are shown in Table 1 .

All estimated regressions are statistically significant and fit well to the empirical data, as indicated by the corresponding values of F-statistics and coefficients of determination. Additionally, relatively low values of variance inflation factors (VIF) do not indicate any serious problems with the multicollinearity of the selected explanatory variables in each of the examined periods of time. A comparison of the coefficients of determination reveals that Model 1 best fits the data for the period 2008-2014, when it was able to explain over $90 \%$ of the variation in banks' stock prices.

As expected, the estimates of regression coefficients $\alpha_{1}$ and $\alpha_{2}$ are positive, indicating that increases in the book values of equity and net earnings of banks corresponded on average with higher market values. The impact of these accounting items on banks' stock prices was statistically significant both before the financial crisis and over the entire examined period. Interestingly, however, net earnings appear to have lost their value relevance after the beginning of the crisis, as indicated by an unacceptably high $p$-value of the coefficient $\alpha_{2}$ (0.391). A possible explanation of this observation might be an increased volatility of net earnings in that period resulting largely from significant fluctuations in impairment 
provisions. Therefore, as net earnings became less predictable, equity investors seemingly attributed higher value relevance to book values of equity which resulted in a slightly increased coefficient $\alpha_{1}$ in the period 2008-2014.

\section{Table 1}

Estimations of Model 1 parameters for the examined periods

\begin{tabular}{|c|c|c|c|c|c|c|c|c|c|c|c|c|}
\hline \multirow{4}{*}{ Parameter } & \multicolumn{12}{|c|}{ Model 1: $\quad \tilde{p}_{t}=\alpha_{0}+\alpha_{1} \times B V P S_{t}+\alpha_{2} \times E P S_{t}+\alpha_{3} \times L_{t}+\varepsilon_{t}$} \\
\hline & \multicolumn{12}{|l|}{ Period } \\
\hline & \multicolumn{4}{|l|}{ 1998-2007 } & \multicolumn{4}{|l|}{ 2008-2014 } & \multicolumn{4}{|l|}{ 1998-2014 } \\
\hline & $\begin{array}{l}\text { estimate/ } \\
\text { value }\end{array}$ & $\begin{array}{l}\text { std. } \\
\text { error }\end{array}$ & $\begin{array}{l}p \text {-va- } \\
\text { lue }\end{array}$ & VIF & $\begin{array}{l}\text { estimate/ } \\
\text { value }\end{array}$ & $\begin{array}{l}\text { std. } \\
\text { error }\end{array}$ & $\begin{array}{l}p \text {-va- } \\
\text { lue }\end{array}$ & VIF & $\begin{array}{l}\text { estimate/ } \\
\text { value }\end{array}$ & $\begin{array}{l}\text { std. } \\
\text { error }\end{array}$ & $\begin{array}{l}p \text {-va- } \\
\text { lue }\end{array}$ & VIF \\
\hline$\alpha_{0}$ & -20.431 & 12.537 & 0.106 & & 13.834 & 14.767 & 0.351 & & -12.741 & 9.717 & 0.191 & \\
\hline$\alpha_{1}$ & 1.551 & 0.131 & 0.000 & 2,241 & 1.869 & 0.148 & 0.000 & 5,534 & 1.544 & 0.099 & 0.000 & 2.898 \\
\hline$\alpha_{2}$ & 4.964 & 0.842 & 0.000 & 2,239 & 0.923 & 1.070 & 0.391 & 5,477 & 4.210 & 0.670 & 0.000 & 2.888 \\
\hline$\alpha_{3}$ & 1.492 & 1.035 & 0.152 & 1,005 & -2.775 & 1.312 & 0.037 & 1,060 & 0.545 & 0.822 & 0.508 & 1.013 \\
\hline $\mathrm{R}^{2}$ & 0.824 & & & & 0.915 & & & & 0.848 & & & \\
\hline Adj. $R^{2}$ & 0.820 & & & & 0.912 & & & & 0.846 & & & \\
\hline F-statistic & 209.714 & & 0.000 & & 330.113 & & 0.000 & & 428.862 & & 0.000 & \\
\hline $\begin{array}{l}\text { Sum of } \\
\text { squared } \\
\text { residuals }\end{array}$ & $635,106.791$ & & & & $185,085.821$ & & & & $878,894.827$ & & & \\
\hline $\mathrm{N}$ & 138 & & & & 96 & & & & 234 & & & \\
\hline
\end{tabular}

Source: own study.

Given the scope of this study, the most important findings are regarding the change in the value relevance of financial leverage (coefficient $\alpha_{3}$ ) in the post-crisis period. It appears that prior to the crisis the extent of financial leverage was positively, although not statistically significant, related to banks' market value. After the start of the crisis, however, this relationship became negative and significant at the 0.05 level, so that in the period 20082014 an increase in the ratio of total assets to equity by 1 resulted, on average, in the fall of bank's stock price by 2.78 PLN. These findings clearly support the key hypothesis of the present study, suggesting that an unprecedented increase of uncertainty in the global capital markets in the aftermath of the crisis induced the equity investors in the Polish banking sector to change their perception of banks' exposure to financial leverage. It appears that in the post-crisis period the market started to punish more leveraged banks causing their market values to decrease.

In the next stage of the research Model 1 was tested for a potential structural break in the regression parameters between the pre-crisis and post-crisis period. The estimated value of the Chow test statistic equalled 4.044 and exceeded the corresponding critical value of the $\mathrm{F}$ distribution at the 0.01 level of significance (3.403) indicating that the impact of the selected explanatory variables was different in each of the examined sub periods. 
In order to evaluate the statistical significance of the differences between the regression coefficients for the periods 1998-2007 and 2008-2014 the parameters of Model 2 were estimated (Table 2).

Table 2

Estimations of Model 2 parameters

\begin{tabular}{|c|c|c|c|}
\hline \multirow[t]{2}{*}{ Parameter } & \multicolumn{3}{|c|}{$\begin{array}{l}\text { Model 2: } \\
\begin{aligned} \tilde{p}_{t}= & \beta_{0}+\beta_{1} \times D_{t}+\beta_{2} \times B V P S_{t}+\beta_{3} \times E P S_{t}+\beta_{4} \times L_{t}+\beta_{5} \times\left(D_{t} \times B V P S_{t}\right)+ \\
& +\beta_{6} \times\left(D_{t} \times E P S_{t}\right)+\beta_{7} \times\left(D_{t} \times L_{t}\right)+\vartheta_{t}\end{aligned}\end{array}$} \\
\hline & estimate/value & standard error & $p$-value \\
\hline$\beta_{0}$ & -20.431 & 10.971 & 0.064 \\
\hline$\beta_{1}$ & 34.265 & 22.666 & 0.132 \\
\hline$\beta_{2}$ & 1.551 & 0.114 & 0.000 \\
\hline$\beta_{3}$ & 4.964 & 0.737 & 0.000 \\
\hline$\beta_{4}$ & 1.492 & 0.906 & 0.101 \\
\hline$\beta_{5}$ & 0.318 & 0.229 & 0.166 \\
\hline$\beta_{6}$ & -4.041 & 1.615 & 0.013 \\
\hline$\beta_{7}$ & -4.267 & 1.981 & 0.032 \\
\hline $\mathrm{R}^{2}$ & 0.858 & & \\
\hline Adj. $R^{2}$ & 0.854 & & \\
\hline F-statistic & 195.838 & & 0.000 \\
\hline N (1998-2014) & 234 & & \\
\hline
\end{tabular}

Source: own study.

The results of the estimation of Model 2 reveal that the aforementioned changes in the regression coefficients for net earnings $\left(\beta_{6}\right)$ and TA/E ratio $\left(\beta_{7}\right)$ proved to be statistically significant at the 0.05 level. The latter finding indicates a prominent shift in investors' attitudes towards financial leverage and thus provides further support for the investigated research hypothesis. Simultaneously, the observed change in the regression coefficient for the book value of equity $\left(\beta_{5}\right)$ should be deemed insignificant, as the corresponding $p$-value reached 0.166 .

The empirical evidence strongly suggests that the perception of leverage by the equity investors in the Polish banking sector changed significantly in the wake of the global financial crisis. Even if prior to the crisis leverage was not considered an important value driver by the capital market, for its seemingly positive impact on banks' stock prices turned out to be statistically insignificant, in the succeeding period this perspective changed completely and higher leverage began to be associated with lower market values. In the light of the conducted analyses both the inverse relationship between banks' leverage and their market values in the post-crisis period and the very shift in the investors' attitudes towards leverage proved to be statistically significant. The outcomes of the present study are; therefore to large extent consistent with the findings of Calomiris and Nissim (2012) in the context of the U.S. market. 


\section{Conclusions}

The results of the study indicate that the impact of financial leverage on the market value in the Polish banking sector changed diametrically after the beginning of the global financial crisis in 2008. In the period preceding the downturn this impact was positive, but not statistically significant, so that the market seemed to award banks for taking on higher leverage in search of increased returns on equity. After the crisis began, however, higher leverage started to be perceived negatively by the equity investors, as it was presumably associated with higher counter-party risk and lower capital adequacy. More leveraged banks could therefore be considered less resilient to potential further adverse shocks and financial losses. As a result, the impact of leverage on the market value of banks became significantly negative. The results of the research also indicate a substantial shift in the value relevance of net earnings in the post-crisis period as their impact on banks' market values decreased and became not statistically significant. The only accounting-based value driver that seemed to be robust to the impact of the global financial crisis was the book value of equity that remained significantly positively related to market values over the entire examined period.

Therefore, the findings of the study demonstrate that the value relevance of financial leverage in the banking sector is highly sensitive to the current macroeconomic conditions and overall market sentiment, which partially justifies the mixed results of prior investigations of this issue in international literature.

In the light of ambiguous international evidence and the results of the present study a thorough diagnosis of the impact of changing macroeconomic conditions on the value relevance of financial leverage in the banking industry seems to require some further investigation. In particular, future research might try to explore whether it is possible to determine an optimal extent of financial leverage that should be taken on by banks to prevent potential negative responses of the capital market during the periods of increased risk aversion.

\section{References}

Abuzayed B., Molyneux P., Al-Fayoumi N. (2009). Market value, book value and earnings: is bank efficiency a missing link? Managerial Finance, 35 (2), 156-179.

Agostino M., Drago D., Silipo D. B. (2011). The value relevance of IFRS in the European banking industry. Review of Quantitative Finance and Accounting, 36 (3), 437-457.

Allen F., Carletti E., Marquez R. (2011). Credit market competition and capital regulation. Review of Financial Studies, 24 (4), 983-1018.

Anandarajan A., Francis B., Hasan I., John K. (2011). Value relevance of banks: global evidence. Review of Quantitative Finance and Accounting, 36, 33-55.

Bank for International Settlements (2010). 80 Annual Report. 1 April 2009-31 March 2010. Bank for Interna Settlements, Basel.

Bolibok P. (2014). Application of the Ohlson model for testing the value relevance of accounting data in Polish banking sector. Zeszyty Naukowe Uniwersytetu Szczecińskiego nr 802, Finanse, Rynki Finansowe, Ubezpieczenia $\mathrm{nr} 65,463-471$.

Calomiris C.W., Nissim D. (2012). Crisis-related shifts in the market valuation of banking activities. NBER Working Paper No. 17868 (pp. 1-53). 
Calomiris C.W., Wilson B. (2004). Bank capital and portfolio management: The 1930 " capital crunch" and the scramble to shed risk. Journal of Business, 77 (3), 421-455.

Cheng I.-H., Hong H., Scheinkman J.A. (2010). Yesterday's heroes: Compensation and creative risk-taking, NBER Working Paper No. 16176 (pp. 1-49).

Dougherty C. (2011). Introduction to econometrics. 4th edition, New York: Oxford University Press Inc.

Hart O., Moore J. (1995). Debt and seniority: An analysis of the role of hard claims in constraining management. American Economic Review, 85, 567-585.

Jordan D.J., Rice D., Sanchez J., Wort D. (2011). Explaining bank market-to-book ratios: Evidence from 2006 to 2009. Journal of Banking and Finance, 35 (8), 2047-2055.

Kalemli-Ozcan S., Sorensen B., Yesiltas S. (2011). Leverage across firms, banks and countries. NBER Working Paper No. 17354 (pp. 1-56).

Mehran H., Thakor A. (2011). Bank capital and value in the cross-section. The Review of Financial Studies, 24 (4), 1019-1067.

Modigliani F., Miller M.H. (1958). The cost of capital, corporate finance and the theory of investment. American Economic Review, 48, 261-297.

Phelan G. (2016). Financial intermediation, leverage, and macroeconomic instability. American Economic Journal: Macroeconomics (forthcoming).

Yang J., Tsatsarosis K. (2012). Bank stock returns, leverage and the business cycle. BIS Quarterly Review, March, 45-59.

\section{WPLYW GLOBALNEGO KRYZYSU FINANSOWEGO NA ZNACZENIE DŹWIGNI FINANSOWEJ DLA WARTOŚCI RYNKOWEJ W POLSKIM SEKTORZE BANKOWYM}

Streszczenie: $\mathrm{Cel}$ - Celem artykułu jest weryfikacja empiryczna wpływu globalnego kryzysu finansowego na znaczenie dźwigni finansowej dla wartości rynkowej w polskim sektorze bankowym.

Metodologia badania - Zastosowane metody badawcze obejmują analizę liniowej regresji wielorakiej oraz test Chowa stabilności oszacowań parametrów modelu. Próba badawcza objęła wszystkie banki komercyjne z siedzibą w Polsce notowane na Giełdzie Papierów Wartościowych w Warszawie w okresie 1998-2014.

Wynik - Rezultaty przeprowadzonych analiz wskazują, że postrzeganie dźwigni finansowej przez inwestorów giełdowych w polskim sektorze bankowym uległo istotnej zmianie od początku globalnego kryzysu finansowego w 2008 r. W okresie poprzedzającym kryzys dźwignia finansowa miała pozytywny, choć nieistotny statystycznie, wpływ na wartość rynkową banków. Jednakże po wybuchu kryzysu ten wpływ stał się istotnie negatywny, co może odzwierciedlać strukturalną zmianę postaw inwestorów, będącą wynikiem znacznie zwiększonej niepewności i awersji do ryzyka w tym okresie.

Originalność/wartość - Bezpośrednie analizy empiryczne wpływu globalnego kryzysu finansowego na znacznie dźwigni finansowej dla wartości rynkowej w sektorze bankowym w literaturze przedmiotu były dotychczas przeprowadzane wyłącznie dla rynku Stanów Zjednoczonych. W szczególności, żadne wcześniejsze prace naukowe nie analizowały tego problemu w specyficznych warunkach polskiego rynku kapitałowego. Niniejszy artykuł podejmuje zatem próbę wzbogacenia istniejącej międzynarodowej i krajowej literatury przedmiotu poprzez wypełnienie przedmiotowej luki.

Słowa kluczowe: bank, wartość rynkowa, dźwignia, kryzys finansowy, znaczenie wartości

\section{Citation}

Bolibok P. (2016). The Impact of the Global Financial Crisis on the Value Relevance of Leverage in the Polish Banking Sector. Finanse, Rynki Finansowe, Ubezpieczenia, 4 (82/2), 679-688. DOI: 10.18276/frfu.2016.4.82/2-59. 